\title{
Model Pengembangan Paradigma Masyarakat Bagi Kepemilikan Rumah yang Terpisah dari Tanah*
}

\author{
Martin Roestamy $^{* * *}$ dan Rita Rahmawati*** \\ Hukum Property, Fakultas Hukum, Universitas Djuanda \\ J1. Tol Ciawi 1 Kotak Pos Ciawi 35 Bogor, Jawa Barat, 16720
}

\begin{abstract}
The main issue causing difficulties for low-income people to get decent housing is the paradigm they have that owning a house means owning the land. This study uses a mixed method approach, in addition to using quantitative data, but also uses a qualitative approach by looking at the profound way, which is related to legal aspects to find a way out of the legal void that is the problem in this study. Results showed that the community paradigma of separated ownership of house and land was low. This study resulted in a formulation of development model of community paradigm of house ownership separated from land ownership. Based on this model, it was concluded that community paradigm of house ownership separated from land ownership could be developed if there were stimulating compensations to eliminate people hesitance about having an apartment.
\end{abstract}

Keywords: development paradigm, house ownership, apartments, low-income people, backlog.

\section{Intisari}

Persoalan utama yang menyebabkan masyarakat berpenghasilan rendah di Indonesia sulit memperoleh rumah adalah adanya paradigma masyarakat tentang kepemilikan rumah yang bermakna kepemilikan tanah. Studi ini menggunakan pendekatan mixed method, di samping menggunakan data kuantitatif, tetapi juga menggunakan pendekatan kualitatif dengan melihat aspek-aspek hukum yang terkait secara mendalam untuk menemukan jalan keluar dari kekosongan hukum yang menjadi permasalahan dalam penelitian ini. Hasil penelitian menunjukkan bahwa paradigma masyarakat tentang kepemilikan rumah yang terpisah dari tanah masih rendah. Penelitian ini juga menghasilkan rumusan model pengembangan paradigma masyarakat bagi kepemilikan rumah yang terpisah dari tanah. Berdasarkan model tersebut, paradigma masyarakat dapat dikembangkan jika terdapat kompensasi menarik dari kepemilikan rumah susun.

Kata Kunci: pengembangan paradigma, kepemilikan rumah, rumah susun, masyarakat berpenghasilan rendah, backlog perumahan.

\section{Pokok Muatan}

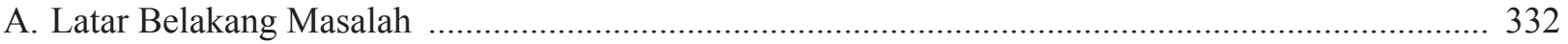

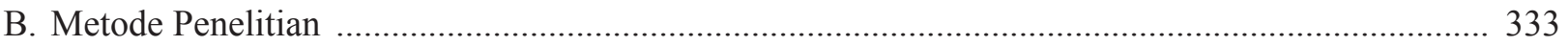

C. Hasil Penelitian dan Pembahasan ............................................................................................. 334

1. Paradigma Masyarakat tentang Kepemilikan Rumah ................................................................ 334

2. Model Pengembangan Paradigma Masyarakat Bagi Kepemilikan Rumah yang Terpisah

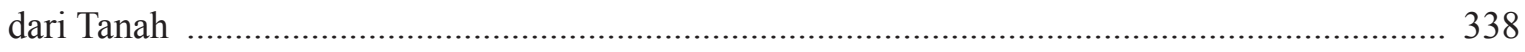

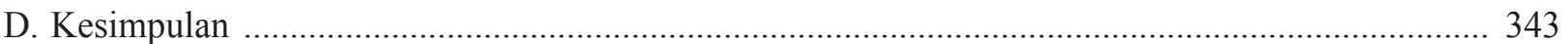

Hasil penelitian yang didanai oleh Direktorat Pendidikan Tinggi Kemenristek untuk skim Hibah Strategis Nasional pada tahun 2016 (JanuariSeptember 2016) untuk mengikuti call for paper Jurnal Mimbar Hukum.

**Alamat korespondensi: martin.roestamy@unida.ac.id.

*** Alamat korespondensi: rita.rahmawati@unida.ac.id. 


\section{A. Latar Belakang Masalah}

Indonesia sebagai negara yang sedang membangun, masih mempunyai sejumlah masalah yang harus diselesaikan, salah satunya kemiskinan. Gejala kemiskinan yang masih bertahan di tengah riuhnya pertumbuhan ekonomi adalah salah satu masalah paling problematis dalam pembangunan dewasa ini. Di Indonesia sampai bulan September Tahun 2014 jumlah penduduk miskin tercatat sebanyak 27,73 juta jiwa atau sekitar 10,96 persen. ${ }^{1}$ Salah satu ciri penduduk miskin adalah ketidakmampuan untuk memiliki rumah diakibatkan pendapatan yang rendah dan nilai jual rumah yang sangat tinggi.

Direktur Jenderal Penyediaan Perumahan Kementerian PUPR, Syarif Burhanuddin menyatakan bahwa, "Berdasarkan data Badan Pusat Statistik (BPS), backlog perumahan pada 2015 sebesar 11,4 juta unit atau menurun dari backlog pada 2010 yang mencapai 13,5 juta unit. Data backlog 2010 tersebut berasal dari aspek kepemilikan rumah." "2 Selanjutnya berdasarkan data BPS Tahun 2016 diketahui bahwa persentase rumah tangga menurut provinsi dan status kepemilikan rumah milik sendiri pada Tahun 1999-2015 adalah sebanyak 82,63 persen. Artinya, rumah tangga yang memiliki rumah di Tahun 2015 sebanyak 82,63 persen atau backlog tinggal 11,4 juta unit. ${ }^{3}$

Pemerintah kabinet kerja era Presiden Joko Widodo yang meneruskan rencana kerja kabinet Presiden Susilo Bambang Yudhoyono berupaya mewujudkan seribu tower dan sejuta unit pada tahun 2015 dalam rangka memenuhi backlog perumahan. Namun realisasinya, pencapaian program tersebut yang dinamakan Program Sejuta Rumah hanya sebanyak 699.770 unit, termasuk di dalamnya rumah swadaya. ${ }^{4}$ Kegagalan tersebut disebabkan oleh banyak faktor antara lain disebabkan karena keterbatasan ketersediaan lahan untuk membangun rumah khususnya bagi rakyat kecil atau Masyarakat Berpenghasilan Rendah (MBR) yang disebabkan karena harga tanah yang semakin mahal. Hal tersebut dapat dilihat dari pesatnya pembangunan pusat perbelanjaan atau mall, gedung perkantoran, perumahan mewah, perhotelan, dan kawasan industry yang mengakibatkan terjadi perubahan paradigma tentang "tanah" yang telah menyimpang dari cita-cita konstitusi yakni "Bumi, air, dan kekayaan yang terkandung di dalamnya dikuasai negara dan digunakan sebesar-besarnya untuk kemakmuran rakyat". 5 Fenomena saat ini, tanah sudah beralih penguasaannya dari pemerintah menjadi penguasaan swasta, bahkan cenderung dikuasai oleh kartel property sehingga tanah sudah berubah fungsi menjadi bahan komoditi bisnis dan bahkan spekulasi para spekulan. ${ }^{6}$

Mahalnya harga tanah menyebabkan harga rumah semakin mahal. Akibatnya MBR menjadi semakin sulit untuk memiliki rumah. Oleh karena itu perlu dicarikan solusi bagi kepemilikan rumah MBR. Deputi Gubernur Provinsi DKI Jakarta bidang Tata Ruang dan Lingkungan Hidup, Oswar Mongkasa menyebutkan bahwa untuk membangun perumahan bagi MBR di wilayah provinsi DKI Jakarta mengalami hambatan terkait harga tanah yang semakin hari kian meningkat sehingga pemerintah mengalami kesukaran untuk menyediakan tanah bagi pembangunan perumahan terjangkau. ${ }^{7}$ Selain itu, Presiden Republik Indonesia

Biro Pusat Statistik, "Jumlah Penduduk Miskin September 2014 Mencapai 27,73 Juta Orang. Website BPS”, http://www.bps.go.id/index.php/ brs/1026, diakses tanggal 25 Oktober 2016

Kementerian Pekerjaan Umum dan Perumahan Rakyat, "Pemerintah Lakukan Penyederhanaan Perizinan Guna Percepat Program Sejuta Rumah", http://pu.go.id/berita/11482/Pemerintah-Lakukan-Penyederhanaan-Perizinan-Guna-Percepat-Program-Sejuta-Rumah, diakses tanggal 25 Oktober 2016.

Biro Pusat Statistik, "Persentase Rumah Tangga menurut Provinsi dan Status Kepemilikan Rumah Milik Sendiri, 1999-2015". https://www. bps.go.id/linkTabelStatis/view/id/1541, diakses Tanggal 25 Oktober 2016.

Kementerian Pekerjaan Umum dan Perumahan Rakyat, "Pemerintah Lakukan Penyederhanaan Perizinan Guna Percepat Program Sejuta Rumah", http://pu.go.id/berita/11482/Pemerintah-Lakukan-Penyederhanaan-Perizinan-Guna-Percepat-Program-Sejuta-Rumah, diakses tanggal 25 Oktober 2016.

Sebagaimana UUD 1945 Pasal 33 Ayat (3) yang memberikan kewenangan kepada negara untuk menguasai tanah sebagai kekayaan bangsa. Martin Roestamy, "Concept of Land Bank Institutional Development for Land Supply for Low-Income Housing Development (MBR)", Makalah, Brain Inspired Cognitive System Conference, Universitas Djuanda, Bogor, 2017.

Oswar Mungkasa, "Penyediaan Tanah Bagi Perumahan LIP melalui Bank Tanah (LandBank) Berbasis Tata Ruang (Kasus: DKI Jakarta)", Makalah, Focus Group Discussion held by The HUD Institute of Indonesia, Grand Zury Hotel, Tangerang, 15 Juni 2017. 
Joko Widodo yang dibenarkan oleh Menteri Agraria dan Tata Ruang/Kepala Badan Pertanahan Nasional Sofjan Djalil menyebutkan untuk pembangunan kepentingan umum di DKI Jakarta pemerintah mengalami kesukaran untuk mendapatkan tanah guna menyediakan tanah bagi kepentingan umum mengingat sebagian besar tanah telah dikuasai oleh para pemodal. Berdasarkan hasil penelitian Institute for Transformation for Justice Program tentang penguasaan tanah berlebihan (latifundia) disebutkan bahwa: "Di Indonesia tanah dikuasai oleh tidak lebih dari 3 persen dari populasi rakyat Indonesia, terdapat 25 kelompok oligopoli yang mendominasi 5,1 juta hektar dari total 10 juta hektar perkebunan yang setara sampai hampir setengah pulau Jawa atau seluas $128.297 \mathrm{KM}^{2}$ dan sebagian dari jumlah tersebut terdiri dari 2 juta hektar belum ditanami, dan sebagiannya menjadi lahan terbengkalai."

Persoalannya, masyarakat perkotaan masih beranggapan bahwa kepemilikan rumah bermakna memiliki tanah juga, padahal dengan perubahan paradigma tentang peran tanah, anggapan kepemilikan rumah sekaligus kepemilikan tanah adalah suatu utopia. Harga tanah yang semakin tak terjangkau jika dibandingkan dengan pendapatan rata-rata rakyat Indonesia khususnya MBR merupakan persoalan yang kurang disadari oleh masyarakat maupun semua pihak pemangku kebijakan. Kendala lainnya untuk mengatasi backlog adalah keterbatasan sumber dana masyarakat untuk membeli rumah sekaligus membeli tanah sehingga menjauhkan antara harapan dan kenyataan sebagaimana yang diharapkan oleh konstitusi dan undang-undang serta peraturan perundangundangan yang berlaku.

Berdasarkan penelitian yang penulis lakukan sebelumya, telah terungkap bahwa pengembangan sistem hukum perumahan masih memerlukan perubahan paradigma, baik terhadap kawasan perumahan dan permukiman, maupun kepemilikan rumah dan bangunan Gedung. ${ }^{9}$ Perubahan paradigma dimaksud meliputi keterkaitan antara kepemilikan rumah dan/atau bangunan gedung menurut pemerintah, peraturan perundang-undangan, dan masyarakat sebagai pengguna. Dengan demikian dapat dikatakan bahwa persoalan utama yang menyebabkan MBR di Indonesia sulit memperoleh rumah adalah adanya paradigma masyarakat tentang kepemilikan rumah yang bermakna kepemilikan tanah. Paradigma ini menyebabkan masyarakat tidak mudah menerima konsep rumah yang terpisah dari tanah seperti Rumah Susun Sewa (RUSUNAWA) $)^{10}$.

Berdasarkan latar belakang di atas, maka perumusan masalah penelitian ini adalah pertama, bagaimana paradigma masyarakat tentang penerapan asas pemisahan horizontal dalam penyediaan pembangunan rumah untuk MBR, dan kedua, langkah-langkah strategis apa yang perlu dilakukan untuk mengembangkan paradigma masyarakat bagi kepemilikan rumah yang terpisah dari tanah dalam upaya percepatan penyediaan perumahan untuk MBR?

\section{B. Metode Penelitian}

Studi ini menggunakan pendekatan yuridis sosiologis, dengan mengelola data-data empiris yang ditemui di lapangan oleh tim peneliti dan dengan menggunakan model mixed method, data kuantitatif dianalisis yang dapat memberikan dorongan kepada peneliti untuk mengkomparasi dengan data kualitatif serta bahan-bahan hukum primer yang kemudian basis penelitian yang menggunakan bahan hukum sekunder yang dijadikan parameter dengan pendekatan teori hukum sebagai pisau analisis untuk menemukan postulat-postulat hukum dengan melihat data empirikal sebagai bahan dasar, sehingga hasil penelitian ini diharapkan dapat memberikan

\footnotetext{
Detiknews, "Ini 10 Raksasa Properti di Indonesia", https://finance.detik.com/properti/d-1967977/ini-10-raksasa-properti-indonesia, diakses pada tanggal 25 Oktober 2016.

Martin Roestamy, et al., 2014, Model Pengembangan Sistem Hukum perumahan Bagi Masyarakat Berpenghasilan Rendah Yang Layak Secara Teknis, Ekonomi dan Sosial, Laporan Penelitian, Universitas Djuanda, Bogor, hlm. 81.

10 Martin Roestamy, "Pengadaan Tanah dalam Perspektif Sosiologi Hukum”, Jurnal Living Law Vol. 7, No. 1, Januari 2015 , hlm. 79-90.
} 
jalan keluar dari kekosongan hukum yang menjadi permasalahan dalam penelitian ini. Pendekatan kuantitatif digunakan untuk mengkuantifikasi data hasil kuesioner tentang persepsi masyarakat tentang kepemilikan rumah yang terpisah dari tanah. Responden penelitian ini adalah 282 orang yang tersebar di empat wilayah kabupaten/kota yaitu; Kota Bogor, Kabupaten Bogor, Kota Depok dan Kota Administratif Jakarta Utara. Sedangkan pendekatan kualitatif digunakan untuk mengetahui data secara lebih mendalam berkenaan dengan harapan dan keinginan masyarakat dan stakeholder terhadap paradigma pembangunan perumahan yang terpisah dari tanah. Data ini dicari melalui teknik pengumpulan data indepth interview dan Focus Group Discussion (FGD). Informan penelitian ini adalah masyarakat berpenghasilan rendah, pengembang perumahan dan Pemerintah Daerah di wilayah sebagaimana disebut di atas. Data yang diperoleh tersebut dimaknai dan dikontruksi berdasarkan perspektif subyektif dari Tim Peneliti. Penekanan pada penggambaran, pemahaman dan pemaknaan atas berbagai fenomena tentang sistem hukum kepemilikan perumahan bagi MBR. Selanjutnya melakukan refleksi atas data yang diperoleh untuk memetakan paradigma masyarakat dan berbagai pemangku kebijakan dan pemangku kepentingan untuk pembangunan perumahan bagi MBR.

\section{Hasil Penelitian dan Pembahasan \\ 1. Paradigma Masyarakat tentang Kepemi- likan Rumah}

Paradigma masyarakat tentang kepemilikan rumah dinilai berdasarkan bentuk rumah yang ditempati dan bentuk rumah yang diinginkan. Berdasarkan indikator bentuk rumah yang ditempati, umumnya responden sebanyak 79,08 persen tinggal di rumah yang berada di atas tanah dengan rumah hanya 1 lantai. Sebanyak 2,13 persen tinggal di rumah tipe kluster, yaitu rumah deret di atas tanah dengan jumlah lantai hanya 1 lantai. Selain itu, ada juga sebanyak 1,06 persen dari responden yang tinggal di rumah susun.

Selanjutnya berkenaan dengan persepsi masyarakat mengenai rumah ideal yang diharapkan/ diinginkan oleh masyarakat berpenghasilan rendah dapat diketahui bahwa dari 282 responden hanya sekitar 2 persen yang memikirkan rumah susun sehat sebagai rumah hunian yang layak dan mereka inginkan. Jika dibandingkan dengan responden yang memilih rumah di atas tanah yang memiliki pekarangan angkanya cukup tinggi yaitu 30 persen. Namun demikian, apabila dilihat secara keseluruhan, mayoritas (48 persen) tidak berpikir soal rumah di atas tanah atau tidak di atas tanah asalkan rumah tersebut memiliki tempat Mandi, Cuci (MCK). Artinya fasilitas MCK dipandang sebagai fasilitas dasar yang harus ada untuk sebuah rumah. Rendahnya presentase responden yang memikirkan untuk tinggal di rumah susun (2 persen) menunjukkan bahwa persepsi masyarakat tentang kepemilikan rumah (paradigma tentang kepemilikan rumah) masih menyimpulkan bahwa rumah harus menyatu dengan tanah. Dengan demikian, hanya sedikit orang yang dapat menerima bahwa rumah terpisah dari tanah (asas pemisahan horizontal).

Berdasarkan penelitian yang dilakukan penulis sebelumnya terungkap pula bahwa penerapan asas pemisahan horizontal dalam pola hubungan antara tanah dengan bangunan di atasnya, pada dasarnya adalah memberikan persepsi terhadap hak atas tanah yang berbeda dari hak kepemilikan atas bangunan. ${ }^{11}$ Hubungan antara hak atas tanah dengan hak atas bangunan atau bagiannya adalah hubungan yang saling terkait namun tidak selalu melekat satu sama lain. Keterkaitan tersebut terletak pada keberadaan bangunan yang berada di atas tanah (walaupun dapat saja bagian dari bangunan tidak secara langsung berada di atas tanah) sebagai hal yang secara fisik sudah terberi (given). Selanjutnya, pembangunan rumah susun sekarang ini sangat berkembang dengan pesat mengingat semakin meningkatnya kebutuhan masyarakat akan tempat

\footnotetext{
11 Martin Roestamy, et al., Op.cit., hlm. 13.
} 
hunian yang layak. Berdasarkan hal tersebut, agar pemenuhan kebutuhan masyarakat akan tempat hunian dapat terakomodasi dengan baik, maka di dalam Undang-Undang Nomor 20 Tahun 2011 tentang Rumah Susun (UU Rusun) menetapkan bahwa selain dapat dibangun di atas tanah hak milik, hak guna bangunan dan hak pakai tertentu, juga diatur pula mengenai pembangunan rumah susun melalui pendayagunaan tanah wakaf. ${ }^{12}$

Tanggapan responden mengenai rumah susun ini cukup beragam. Dari 282 responden, sebanyak 38 orang $(13,48$ persen) menyatakan berminat, 213 responden $(75,53$ persen $)$ menyatakan tidak berminat dan 31 responden (10,99 persen) tidak menjawab. Responden yang tidak menjawab tersebut masih memiliki kemungkinan untuk mempertimbangkan rumah susun sebagai rumah hunian.

\section{a. Rumah Susun Belum Menjadi Pilih- an bagi MBR}

Pada awal penelitian yang dilakukan oleh penulis, tergambar bahwa masalah security tenure merupakan faktor signifikan dari harapan masyarakat yang pada kenyataannya memiliki penghasilan yang sangat terbatas. Keadaan ini hampir dapat dikatakan menjadi persoalan utama dari backlog perumahan di Indonesia. Kelayakan rumah yang diharapkan oleh responden (masyarakat MBR) yaitu layak secara teknis, sosial dan ekonomi. ${ }^{13}$ Layak secara teknis artinya harus memenuhi unsur-unsur sebagai berikut:

a. Rumah sederhana berukuran Type $21 / 60$, Type $36 / 72$, atau di atas $100 \mathrm{~m}^{2}$.

b. Bangunan rumah harus mempunyai konstruksi yang kuat.

c. Rumah harus awet dan kuat.

d. Rumah harus indah dan nyaman dihuni.

e. Tersedianya pembuangan air kotor dan kotoran (sanitasi), serta unsur kebersihan dan kesehatan menjadi utama.

f. Sekurang-kurangnya mempunyai tiga ruang (kamar) yang tertutup, yang berfungsi sebagai satu ruang untuk kamar tidur, satu ruang kamar mandi dan toilet, serta satu ruang serbaguna yang bisa berfungsi sebagai ruang tamu, ruang keluarga atau bahkan ruang makan dan dapur.

Adapun kelayakan secara sosial dapat dikemukakan sebagai berikut:

a. Keadaan lingkungan hunian berdekatan dengan tetangga dan saling kenal.

b. Rumah yang minimal mampu menampung keluarga inti yaitu ayah, ibu, dan anak.

c. Adanya persyaratan khusus bagi sebuah bangunan rumah untuk MBR, yaitu: kebersihan sebagai faktor utama kenyamanan.

d. Arah Rumah menyesuaikan dengan tradisi budaya masyarakat setempat.

e. Lingkungan pemukiman (perumahan) dipersyaratkan memiliki fasilitas peribadatan sebagai fasilitas utama dilingkungan tersebut.

Kriteria selanjutnya yang dicari oleh MBR adalah pemukiman tersebut memiliki akses yang dekat dengan fasilitas pendidikan dan olah raga. Setelah itu, pertimbangan berikutnya adalah fasilitas transportasi yang baik dan fasilitas belanja yang bisa dijangkau dengan fasilitas transportasi yang baik. Adapun kelayakan secara ekonomi yang dimaksud adalah rumah yang menyiapkan segala kebutuhan standar rumah, namun dapat diperoleh dengan harga terjangkau. Walau demikian, surat-surat kepemilikan atas rumah/bangunan menjadi faktor penting yang menjadi pertimbangan dari MBR dalam memilih sebuah rumah hunian. 
Kebiasaan masyarakat yang guyub dengan perumahan rakyat dan keluarga atau pemukiman kumuh tetapi memiliki suasana kebersamaan, iklim kekerabatan, keakraban, dan suasana pedesaan menjadikan rumah dengan batas tembok-tembok dan beton akan mengubah tradisi kehidupan bebas (tanpa aturan yang baku). Hal ini menyebabkan rumah susun sebagai sebuah pilihan kehidupan yang lain dan tak menyenangkan. Oleh karena itu, banyak diantara responden yang tinggal di rumah susun hanya karena keterpaksaan dari program resettlement. Harus dicatat pula bahwa penduduk sekitar Jabodetabek yang diantaranya menjadi objek penelitian mayoritas adalah para pendatang dari segenap pelosok penjuru tanah air sehingga budaya desa tempat asal masyarakat tersebut masih terasa dan ingin dipertahankan. Kehidupan rumah susun menghendaki perubahan paradigma dan budaya sesuai dengan tatanan dan aturan yang berlaku baik diatur oleh pemerintah maupun oleh lingkungan. Wajar jika dari penelitian terdahulu terdapat angka yang signifikan mengenai penolakan bertempat tinggal dan menghuni rumah susun karena harus memiliki paradigma baru.

\section{b. Alasan Penolakan MBR Terhadap Penerapan Asas Horizontal dalam Sistem Perumahan}

Ada banyak alasan mengapa masyarakat tidak menyukai tinggal di rumah susun. Berdasarkan hasil penelitian diketahui bahwa salah satu alasan responden tidak menginginkan rumah susun tersebut karena adanya pemisahan kepemilikan atas tanah dan bangunan. Beberapa persepsi masyarakat mengenai hal ini dapat dikemukakan, sebagai berikut:

a. Bagi masyarakat kepemilikan surat-surat atas tanah dan bangunan sangat penting sehingga penawaran rumah susun sebagai alternatif hunian sulit untuk dapat diterima karena ketidakpahaman masyarakat tentang konsep rumah susun dan status kepemilikannya.

b. Keberadaan rumah susun dalam satu bangunan rumah memunculkan pertanyaan baru mengenai kepemilikan bangunan. Masyarakat masih merasa belum jelas tentang hak dan kewajiban dari penghuni rumah susun dan kaitannya dengan surat-surat kepemilikan bangunan, Hal ini lah yang membuat masyarakat merasa tidak nyaman dan waswas, karena ketidakjelasan mengenai hak atas tanah dan bangunan.

c. Ada juga alasan yang dikemukakan tersebut berkenaan dengan ketakutan terjadinya sengketa dengan sesama penghuni rumah susun; "Tidak enak, lebih baik mengontrak, karena tidak bisa berbuat apa-apa saat terjadi sengketa."

d. Konsep rumah susun dengan kepemilikan terpisah antara bangunan rumah dan tanah masih dipandang membingungkan masyarakat. Dalam pandangan masyarakat selama ini masih melekat bahwa tanah dan bangunan adalah kepemilikan yang menyatu, tidak boleh dipisahkan. Masyarakat merasa tidak aman karena tidak memiliki surat kepemilikan, sehingga takut suatu hari akan terjadi pembongkaran. Oleh karena itu tidak setuju, karena berkeinginan hak tanah dan kepemilikan bangunan milik sendiri, jika tanahnya dimiliki pemerintah, kemungkinan besar akan diambil sewaktu-waktu. Misalnya jika menempati tanah yang masih milik pemerintah sedangkan bangunan milik pribadi, lalu terjadi penyelidikan antara pemegang tanah dan bangunannya, maka akan menjadi permasalahan baru. Oleh karena itu, agar 
aman, nyaman dan tidak sengketa, mungkin lebih kuat hak atas tanah merupakan bagian dari bangunan yang dimiliki. jika tanah milik, maka tidak perlu berpindah-pindah dan menjadi hak milik yang tetap selamanya. Karenanya, tidak setuju tinggal di rumah susun, yang mengakibatkan hidup tidak tenang, disebabkan ada kekhawatiran suatu saat akan terusir.

Sinyal pemisahan kepemilikan rumah dan/atau bangunan gedung telah termaktub dalam Undang-undang dan hukum adat antara lain:

a. Undang-Undang Pokok Agraria Nomor 5 Tahun 1960, Pasal 44 ayat (1): "Seorang atau suatu badan hukum mempunyai hak sewa atas tanah, apabila ia berhak menggunakan tanah milik orang lain untuk keperluan bangunan, dengan membayar kepada pemiliknya, sejumlah uang sebagai uang sewa."14

b. Undang-Undang Bangunan Gedung Nomor 28 Tahun 2002, Pasal 8 ayat (1): "Setiap bangunan gedung harus memenuhi persyaratan administratif yang meliputi:

a. status hak atas tanah, dan/ atau izin pemanfaatan dari pemegang hak atas tanah;

b. status kepemilikan bangunan gedung; dan

c. izin mendirikan bangunan gedung;

sesuai ketentuan peraturan perundang-undangan yang berla- ku." 15

Dalam penjelasan juga disebutkan bahwa: "Status kepemilikan bangunan gedung merupakan surat bukti kepemilikan bangunan gedung yang dikeluarkan oleh Pemerintah Daerah berdasarkan hasil kegiatan pendataan bangunan Gedung." 16

c. UURS Nomor 20 Tahun 2011, Pasal 47 dan Pasal 48

\section{Pasal 47}

(1) Sebagai tanda bukti kepemilikan atas sarusun di atas tanah hak milik, hak guna bangunan, atau hak pakai di atas tanah negara, hak guna bangunan atau hak pakai di atas tanah hak pengelolaan diterbitkan SHM sarusun. (2) SHM sarusun sebagaimana dimaksud pada ayat (1) diterbitkan bagi setiap orang yang memenuhi syarat sebagai pemegang hak atas tanah. ${ }^{17}$

Pasal 48

Sebagai tanda bukti kepemilikan atas sarusun di atas barang milik negara/ daerah berupa tanah atau tanah wakaf dengan cara sewa, diterbitkan SKBG sarusun. ${ }^{18}$

d. Dalam Hukum Adat sebagaimana di kenal di beberapa daerah seperti antara lain: Magersari (Yogyakarta), Grand Sulthan (Sumatera Utara), Tanah Ulayat (Sumatera Barat), Tanah Subak (Bali) yang mempraktikkan kepemilikan terpisah antara tanah dengan bangunan yang ada di atasnya. Jadi, hampir semua daerah memiliki paradigma pemisahan kepemilikan antara tanah dan bangunan. ${ }^{19}$

Masalah utama yang kurang disadari untuk mengatasi backlog adalah keterbatasan

\footnotetext{
Pasal 44 ayat (1) Undang-Undang Nomor 5 Tahun 1960 tentang Pokok-Pokok Agraria (Lembaran Negara Republik Indonesia Tahun 1960 Nomor 104, Tambahan Lembaran Negara Republik Indonesia 2043).

15 Pasal 8 ayat (1) Undang-Undang Nomor 28 Tahun 2002 tentang Bangunan Gedung (Lembaran Negara Republik Indonesia Tahun 2002 Nomor 134, Tambahan Lembaran Negara Republik Indonesia Nomor 4247).

16 Penjelasan Undang-Undang Nomor 28 Tahun 2002 tentang Bangunan Gedung (Lembaran Negara Republik Indonesia Tahun 2002 Nomor 134 , Tambahan Lembaran Negara Republik Indonesia Nomor 4247).

17 Pasal 47 Undang-Undang Nomor 20 Tahun 2011 tentang Rumah Susun (Lembaran Negara Republik Indonesia Tahun 2011 Nomor 108, Tambahan Lembaran Negara Republik Indonesia Nomor 5252).

18 Pasal 48 Undang-Undang Nomor 20 Tahun 2011 tentang Rumah Susun (Lembaran Negara Republik Indonesia Tahun 2011 Nomor 108, Tambahan Lembaran Negara Republik Indonesia Nomor 5252).

19 Lihat Martin Roestamy, 2008, Kepastian Hukum atas Kepemilikan Rumah dan Bangunan Gedung oleh Investor Asing dikaitkan dengan Asas Nasionalitas dalam Sistem Hukum Pertanahan Indonesia, Disertasi, Program Doktor Ilmu Hukum, Universitas Padjadjaran, Bandung.
} 
sumber dana masyarakat untuk membeli rumah sekaligus membeli tanah. Dalam bidang properti, tanah bukan saja berfungsi sebagai tapak bangunan, akan tetapi sudah menjadi komoditas bisnis. Dalam Pasal 48 ayat (1) Undang-undang Nomor 20 Tahun 2011 tentang Rumah Susun disebutkan bahwa Sebagai tanda bukti kepemilikan atas sarusun di atas barang milik negara/daerah berupa tanah atau tanah wakaf dengan cara sewa diterbitkan Surat Kepemilikan Bangunan Gedung (SKBG) sarusun. ${ }^{20}$ Substansi pasal tersebut mengadopsi pemikiran kepemilikan rumah susun yang terlepas dari kepemilikan tanah, kepemilikan bangunan gedung diberikan dengan menerbitkan SKBG. Dalam teori hukum, paham tersebut dikenal dengan asas pemisahan horizontal yang artinya kepemilikan tanah terpisah dengan kepemilikan benda di atasnya.

Tidak semua pakar menyepakati penerapan asas pemisahan horizontal sepenuhnya. Beberapa pakar menganggap perlunya penerapan asas ini tanpa menegaskan penerapan asas pelekatan. Mariam Darus Badrulzaman menyatakan bahwa: "Menurut hemat kami, dilihat dari kebutuhan masyarakat yang berkembang, maka accessie vertical untuk tujuan tertentu perlu dipertahankan karena suatu benda tanpa accessie tidak ada artinya dijadikan obyek hukum". ${ }^{21}$

A. P. Parlindungan juga memiliki pendapat yang serupa mengenai penerapan asas pemisahan horizontal sebagai berikut: "Prinsip pemisahan horizontal digunakan dengan tetap membuka jalan untuk mempertahankan asas pelekatan (accessie) vertikal. Jadi accessie tidak dipergunakan secara murni sebagaimana dianut dalam KUH Perdata, akan tetapi sudah dengan perlunakan, sesuai dengan suasana UUPA dan kodifikasi Hukum Benda (Hak Kemilikan) Nasional". ${ }^{22}$

Kedua pakar di atas memiliki pandangan bahwa penerapan asas pemisahan horizontal harus diimbangi dengan asas pelekatan vertikal karena kebutuhan-kebutuhan. Titik tekan kedua pakar di atas adalah asas pemisahan horizontal sebagai salah satu asas yang dianut UUPA untuk mengimbangi asas pelekatan vertikal sebagaimana diatur dalam KUH Perdata. Sementara itu, Mochtar Kusumaatmadja mengatakan bahwa:

Dalam hukum tanah, khususnya yang berkaitan dengan pembangunan gedung, konsep hukum adat tanah yang memisahkan pemilikan tanah dari bangunan di atasnya dapat kiranya memberikan jalan keluar pada masalah-masalah yang timbul dalam pembangunan gedung atas tanah milik orang lain, khususnya dalam pembangunan rumah susun. Pemisahan horizontal ini yang merupakan suatu asas yang lama dikenal dalam hukum adat dan dalam hukum tanah atau kebendaan di negara barat sudah dikenal juga, tetapi belum di negaranegara yang hukum kebendaan dalam hukum perdatanya masih tertinggal seperti Indonesia. ${ }^{23}$

Pendapat di atas menggambarkan bahwa penerapan asas pemisahan horizontal justru sangat diperlukan dengan adanya transaksi tanah yang "berbaju lama" (seperti praktik numpang, magersari) dengan "model" yang baru".

2. Model Pengembangan Paradigma Masyarakat Bagi Kepemilikan Rumah yang Terpisah dari Tanah

Selanjutnya Focus Group Discussion dengan MBR, pemerintah dan pengembang perumahan menghasilkan rumusan model pengembangan paradigma masyarakat bagi kepemilikan rumah

Pasal 48 ayat (1) Undang-Undang Nomor 20 Tahun 2011 tentang Rumah Susun (Lembaran Negara Republik Indonesia Tahun 2011 Nomor 108, Tambahan Lembaran Negara Republik Indonesia Nomor 5252).

Mariam Darus Badrulzaman, 1997, Mancari Sistem Hukum Benda Nasional, BPHN- DEPKEH dan penerbit Alumni, Bandung, hlm. 39.

A.P. Parlindungan, 1983, Aneka Hukum Agraria, Alumni, Bandung, hlm. 106.

Mochtar Kusumaatmadja, Majalah Hukum Nomor: 1 Tahun 1995, Badan Pembinaan Hukum Nasional, hlm. 271. 
yang terpisah dari tanah. Berdasarkan model tersebut, paradigma masyarakat dapat dikembangkan jika terdapat kompensasi menarik dari kepemilikan rumah susun yaitu dengan cara menghilangkan berbagai ketakutan masyarakat dan menggantikannya dengan berbagai keuntungan yang ditawarkan pemerintah bagi kepemilikan rumah tanpa tanah. Selain itu pemerintah perlu berperan untuk mendorong masyarakat mengubah paradigma berpikir berdasarkan kesadaran sendiri.

Model pengembangan paradigma masyarakat bagi kepemilikan rumah yang terpisah dari tanah dilakukan untuk mempercepat penyediaan rumah bagi MBR. Hal ini merupakan rancangan kebijakan perumahan bagi MBR untuk mengarahkan paradigma masyarakat tentang konsep kepemilikan rumah dari penggunaan asas pelekatan kepada asas pemisahan horizontal sehingga dapat dijadikan bahan dasar menyusun kebijakan hukum dalam percepatan pembangunan rumah untuk rakyat khususnya MBR.

Pengembangan paradigma MBR diwujudkan melalui adanya asas pemisahan horizontal dalam Undang-Undang Rumah Susun (UURS) Tahun 2011. Cita-cita untuk mewujudkan penyediaan perumahan bagi MBR dapat lebih mudah terwujud sepanjang rakyat tidak harus membeli tanah dalam program penyediaan tanah oleh beberapa stake holder perumahan. Pengadaan tanah seharusnya dilakukan oleh Pemda, dana CSR BUMN atau APBN dan dapat pula dengan sistem sewa atau wakaf. Apabila konsep dan model pendekatan asas pemisahan horisontal dalam pembangunan rakyat untuk MBR yang dihasilkan dari kegiatan penelitian ini sudah dapat diadopsi secara utuh dalam suatu aturan hukum tertentu dalam bidang perumahan, maka percepatan penyediaan rumah untuk MBR akan terwujud. Dengan demikian, tanggung jawab Negara dalam penyediaan rumah untuk rakyat dapat dijalankan dan hak masyarakat unruk mendapatkan tempat tinggal yang layak dapat terpenuhi sesuai dengan amanat UUD 1945.

Hasil wawancara dengan MBR menunjukkan bahwa masyarakat berpenghasilan rendah memberikan prasyarat bagi perubahan paradigma perumahan ke arah pemisahan horizontal antara rumah dan tanah (contohnya rumah susun), sebagai berikut: ${ }^{24}$

1. Ketahanan lingkungan;

2. Ketahanan sosial;

3. Ketahanan ekonomi;

4. Harga terjangkau;

5. Prosedur mudah; dan

6. Security tenure.

Ketahanan lingkungan dimaknai sebagai keamanan publik secara proporsional dari bahaya-bahaya lingkungan yang diakibatkan oleh proses-proses alamiah atau buatan-manusia karena keteledoran, kecelakaan, salah-kelola, atau kesengajaan. Ketahanan sosial yang dimaksud dalam konteks penyediaan rumah susun (asas pemisahan horizontal) adalah ketangguhan individu yang difasilitasi dengan berbagai infrastruktur sosial, yaitu adanya akses terhadap fasilitas transportasi, akses terhadap fasilitas kesehatan, akses terhadap fasilitas pendidikan, adanya ruang publik untuk memungkinkan individu-individu tersebut dapat berinteraksi secara individu-individu maupun kelompok. Ketahanan ekonomi berkaitan dengan kemudahan akses dalam ke tempat kerja, mudahnya para penghuni perumahan untuk mendapatkan pekerjaan di sekitar lingkungan perumahan. Adapun yang dimaksud dengan harga terjangkau kaitannya dengan harga perumahan dapat dijangkau oleh penghuni dengan penghasilan rendah. Sementara itu, prosedur yang mudah dan sederhana adalah proses pengurusan sehingga masyarakat berpenghasilan rendah dapat mengurus kepemilikan rumah susun dan dapat dengan mudah untuk menempatinya. ${ }^{25}$

Adapun berkenaan dengan security tenure, menurut Bruce dalam Review of tenureterminology, ${ }^{26}$

\footnotetext{
Wawancara Tim Peneliti STRANAS 2016 dengan responden masyarakat Citayam, Cilebut, Bojonggede dan Tanjung Priok pada periode Juni hingga Agustus 2016

5 Lihat Martin Roestamy, et al., Op.cit., hlm. 102.

26 JW Bruce, 1998, "Review of tenure terminology", Tenure Brief No. 1, University of Wisconsin-Madison, USA.
} 
istilah tenure berasal dari jaman feodal Inggris. Setelah menduduki Inggris tahun 1066, Bangsa Normandia menghapuskan hak-hak masyarakat atas tanahnya, dan mengganti hak tersebut hanya sebagai pemberian grant (bantuan) dari pemerintahan baru. Beberapa sumber menjelaskan bahwa kata tenure berasal dari kata dalam bahasa Latin "tenere" yang mencakup arti: memelihara, memegang, memiliki. Land tenure berarti sesuatu yang dipegang dalam hal ini termasuk hak dan kewajiban dari pemangku lahan ("holding or possessing" = pemangkuan atau penguasaan). ${ }^{27}$ Oleh karena itu, dapat dipahami bahwa Land tenure tidak semata-mata kaitannya dengan kepemilikan namun dapat saja dengan penguasaan, pemanfaatan, atau penguasaan untuk hak pemangkuan lahan seperti PERUMPERUMNAS atau Kawasan Industri. Sistem land tenure sesungguhnya merupakan keseluruhan sistem dari pemangkuan yang diakui oleh pemerintah secara nasional, maupun oleh sistem lokal. Sebuah sistem land tenure sulit dimengerti kecuali dikaitkan dengan sistem ekonomi, politik dan sosial yang mempengaruhinya. ${ }^{28}$

Berkenaan dengan kepentingan penelitian ini, maka masalah tenurial sistem ini akan dilihat dalam dua konsep yaitu sebagai sekumpulan atau serangkaian hak-hak (tenure system is a bundle of rights) yang di dalamnya juga terkandung makna kewajiban (obligation) serta bisa juga dimaknai sebagai hak akses (bundle of power). Berkenaan dengan bundle of right (bundle of property right) mengambil teori Schlager dan Ostrom dalam Rahmawati bahwa bundel hak seseorang (the bundle of rights) dapat menentukan berapa banyak orang bersedia untuk berinvestasi di property. Selain itu, Schlager dan Ostrom menyimpulkan bahwa pembentukan rezim manajemen yang efektif harus memperhitungkan insentif yang memadai. ${ }^{29}$ Lebih jelasnya konsep mengenai property right dengan mengacu pada pendapat yang dapat dibedakan dalam beberapa tipe hak kepemilikan (property rights), sebagai berikut: ${ }^{30}$

1. Access rights: the right to enter the territory of resources that have clear boundaries and to enjoy the benefits of non extractive

2. Withdrawal right: the right to utilize the resources or the right to produce

3. Management right: the right to determine the operational rules of resource use.

4. Exclusion right: the right to determine who should have the right to access and how access rights are transferred to other parties

5. Alienation right: the right to sell or lease part or all of the collective rights mentioned above.

Dalam kasus rumah susun, tenure bukan hanya dimaknai sebagai bundle of right, tetapi bisa jadi hanya sebagai bundle of power. Sebagaimana dikemukakan bahwa akses seringkali lebih penting daripada hak formal. ${ }^{31}$ Oleh karena itu perlu ada pengembangan definisi "akses" mengingat kecenderungan masa lalu untuk menggabungkan akses dengan properti. Akses lebih dimaknai seperti seikat kekuasaan (bundle of powers) dan properti lebih seperti seikat hak (bundle of rights). ${ }^{32}$

Persoalannya, dalam kasus rumah susun ada hal-hal yang sifatnya bundle of right, tetapi ada hal yang bersifat bundle of power. Bahkan ada beberapa fasilitas yang termasuk fasilitas umum yang dimanfaat secara bersama-sama (sumberdaya kolektif). Dalammemahami keberadaansumberdaya kolektif (dalam rezim properti umum) tersebut dibedakan sumberdaya milik umum yang memiliki

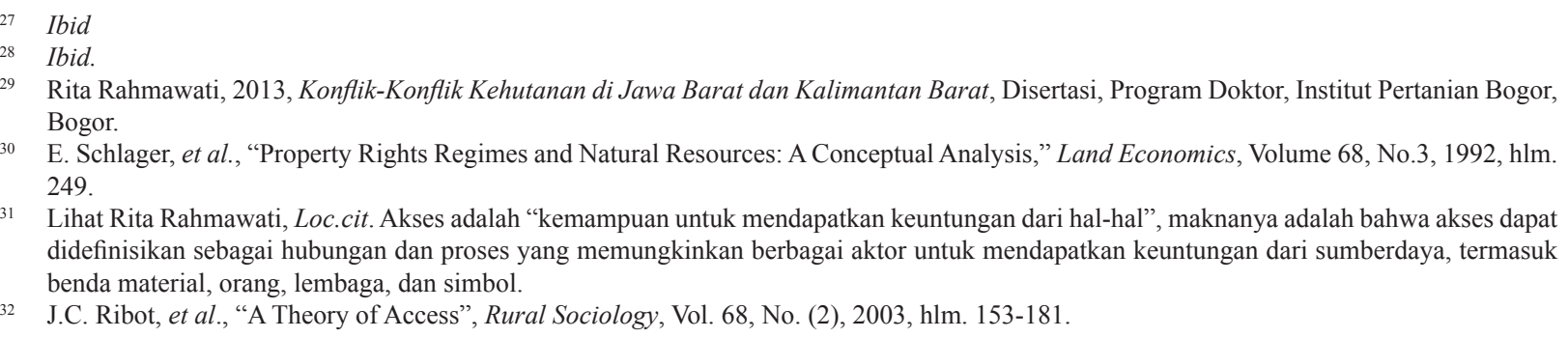


akses terbuka sebagaimana yang dikemukakan oleh McKean sebagai berikut:

These regimes are often incorrectly conflated with common-pool resources, which she defines as "open-access resources available to anyone - very difficult to protect and very easy to deplete." (p. 29) In contrast, a common property regime "is a propertyrights arrangement in which a group of resource users share rights and duties toward a resource." (p. 30) McKean notes that "when a group of individuals and the property rights they share are well defined, common property should be classified as shared private property - a form of ownership; that should be of great interest to anyone who believes that private property rights promote long time horizons and responsible stewardship of resource. ${ }^{33}$

Berdasarkan pemaparan diatas tampak bahwa sumberdaya yang termasuk dalam kepemilikan umum dengan akses terbuka memungkinkan setiap orang untuk mengaksesnya sehingga sangat sulit dijaga. Sebaliknya, rezim milik umum adalah pengaturan hak properti di mana sekelompok pengguna properti tersebut berbagi hak dan kewajiban. ${ }^{34}$ Selanjutnya ketika sekelompok individu dan hak properti bersama tersebut didefinisikan dengan baik, maka milik bersama tersebut harus diklasifikasikan sebagai milik pribadi bersama yang harus menjadi perhatian besar bagi siapa saja yang percaya bahwa hak milik pribadi lebih bertahan lama dan bertanggung-jawab dalam pengelolaannya daripada milik bersama. ${ }^{35}$ Persoalan inilah yang banyak menjadi kegundahan dari para informan untuk memutuskan berada tinggal di rumah susun.

Pengembangan paradigma dari pemikiran tentang rumah harus menyatu dengan tanah ke arah paradigma azas pemisahan horizontal memerlukan dua hal:

1. Proses perubahan pengetahuan dan pemahaman;

2. Pemenuhan prasyarat yang diminta
Peningkatan wawasan dan pemahaman dapat dilakukan melalui aktivitas pelatihan, sosialisasi dan komunikasi yang dilakukan oleh para pemangku kepentingan, khususnya Pemerintah, LSM dan Perguruan tinggi. Sedangkan pemenuhan prasyarat dapat dilakukan oleh para pemangku kepentingan khususnya pemerintah dan pengembang perumahan dengan cara menyediakan rumah susun yang memenuhi ketahanan lingkungan, ketahanan sosial, ketahanan ekonomi, harga terjangkau, prosedur mudah, kejelasan security tenure dan adanya ruang public (public sphare).

Berdasarkan pembahasan di atas, maka dapat dikemukakan model pengembangan paradigma masyarakat bagi kepemilikan rumah yang terpisah dari tanah untuk mempercepat penyediaan rumah bagi masyarakat berpenghasilan rendah, sebagai berikut:

\section{Bagan 1.}

\section{Model Pengembangan Paradigma Masyarakat Bagi Kepemilikan Rumah Yang Terpisah Dari Tanah}

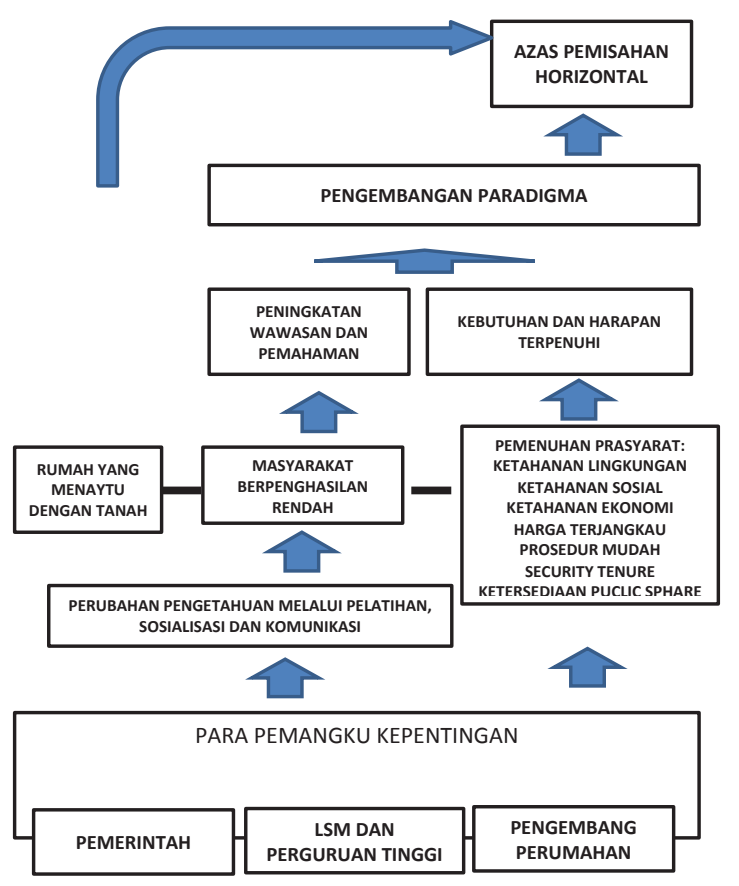

Sumber: Diolah Penulis, 2016.

\footnotetext{
33 M.A. McKean, "Nesting Institutions For Complex Common-Pool Resource Systems", in J. Graham, et al., 2002, Proceedings of the 2nd International Symposium on Landscape Futures, Institute for Rural Futures and University of New England, London, hlm. 29-30. 
Berdasarkan model di atas diketahui bahwa penyediaan perumahan bagi MBR harus disertai dengan perubahan paradigma masyarakat tersebut dari yang asalnya berpandangan bahwa rumah harus menyatu dengan tanah ke dalam pandangan baru tentang ass pemisahan horizontal. Perubahan paradigma tersebut juga harus memberikan format baru kebijakan pemerintah dalam penyediaan perumahan yang dipersyaratkan oleh MBR yaitu adanya pemenuhan berbagai prasyarat. Dengan demikian, dapat dikatakan bahwa pengembangan paradigma masyarakat harus dibarengi dengan adanya kebijakan pemerintah tentang penyediaan perumahan bagi MBR misalnya kebijakan subsidi perumahan.

Berbagai model penyediaan perumahan murah bagi MBR ini dapat meniru kebijkan-kebijakan yang dilakukan oleh negara maju. Sebagai contoh misalnya kebijakan subsidi perumahan di Amerika untuk masyarakat pekerja berpenghasilan rendah. Tanpa subsidi, masyarakat berpenghasilan rendah harus mengeluarkan biaya perumahan hampir 50 persen dari pendapatannya sebagaimana dikemukakan oleh Jacqueline Leavitt dan Teresa Lingafelter bahwa "without the benefit of housingsubsidy programs, low-income people often pay more than half their incomes on housing". ${ }^{36}$

David P. Varady dan Carole C. Walker mengemukakan tentang subsidi perumahan berbasis penyewa. Subsidi berbasis penyewa (voucher perumahan) dapat membantu untuk deconcentrate kemiskinan dan meningkatkan kualitas hidup keluarga berpenghasilan rendah. ${ }^{37}$ Selain itu, di Alameda County, California subsidi telah terbukti membantu keluarga pindah ke lingkungan yang lebih aman dan anak-anak memperoleh sekolah umum yang lebih baik yaitu dengan The Gautreaux
Assisted Housing Program and The Moving to Opportunity (MTO). ${ }^{38}$

Menurut Carey Addison, Sumei Zhan dan Bradley Coomes bahwa pasar perumahan dapat dipengaruhi oleh praktek-praktek perencanaan perumahan dengan menekankn pada isu sosial, administrasi dan ekonomi yang memungkinkan tercapainya pembangunan perumahan yang terjangkau. Lebih lanjut, dinyatakan pula sebagai berikut:

Housing markets can be affected by smart growth-related planning practices, ranging from growth management policies to various urban design tools such as transit-oriented development and urban infill. The review concludes by emphasizing several important social, administrative, and economic issues facing a successful integration of smart growth and affordable housing goals, and discusses possible solutions for maintaining affordability. ${ }^{39}$

Sekalipun beberapa penelitian membuktikan bahwa perumahan yang terjangkau memberi manfaat bagi MBR, namun ada juga pihak-pihak yang mengklaim bahwa perumahan yang terjangkau tidak membawa keuntungan kepada masyarakat, dan bahkan mengancam nilai properti lingkungan. Pendapat tersebut kemudian dipatahkan melalui hasil penelitian dari Elizabeth J. Mueller dan J. Rosie Tighe yang membuktikan adanya hubungan antara penyediaan perumahan yang terjangkau dengan kualitas dan manfaat yang lebih besar untuk masyarakat terutama dibidang kesehatan dan pendidikan. Lebih jelasnya, sebagai berikut:

Opponents often claim that affordable housing brings no net benefits to the community, and that it threatens neighborhood property values. This review considers existing evidence regarding the relationship between

\footnotetext{
Jacqueline Leavitt, et al., "Low Wage Workers and High Housing Costs", Labor Studies Journal, Vol. 30, No. 2, Juni 2005, hlm. 41-60. David P. Varady, et al., "Housing Vouchers and Residential Mobility", Journal of Planning Literature, Vol. 18, No. 1, August 2003, hlm. 1730 .

39 Carey Addison, et al., "Smart Growth and Housing Affordability. A Review of Regulatory Mechanisms and Planning Practices", Journal of Planning Literature, Vol. 28, No. 3, August 2013, hlm. 215-257.
} 
provision of quality affordable housing and benefits to the larger community. Evidence is considered in the areas of health and education. ${ }^{40}$

Berdasarkan tulisan di atas, keberadaan subsidi pemerintah menjadi sangat penting. MBR dapat memiliki rumah yang layak dengan harga terjangkau karena sebagian dana dibayar melalui subsidi. Bentuk subsidi pemerintah dapat berupa bantuan langsung tunai, voucer perumahan, serta pemakaian tanah-tanah pemerintah untuk perumahan. Masyarakat berpenghasilan rendah memperoleh harga yang terjangkau karena hanya membayar biaya bangunannya sedangkan tanah tidak dibayar karena disediakan oleh pihak lain, dalam hal ini pemerintah, kerjasama pemerintah dan swasta, CSR pihak swasta, atau wakaf.

Hasil FGD dengan seluruh stakeholder menyarankan perlu adanya bank tanah yang disiapkan oleh pemerintah. Tanah tersebut bisa berasal dari cadangan tanah untuk fasilitas sosial yang diberikan oleh pengembang perumahan, tanah wakaf, atau tanah yang dibeli melalui Anggaran Pemerintah Daerah (APBD).

Ide tentang penyediaan tanah untuk membangun perumahan terjangkau ini juga pernah dikemukakan oleh James Meehan, hanya saja tanah tersebut diperoleh bukan dari pemerintah melainkan dari masyarakat yang disebut "The community land trust (CLT)" sebagaimana dikemukakan sebagai berikut:

The community land trust (CLT) is a social invention designed to solve several problems in land ownership, from affordability to preservation. This article traces the history of the CLT from concept to implementation, through a network of theorists and activists, and discusses the present extent of CLTS in the United States. It concludes with a case study of the Dudley Street Neighborhood Initiative (DSNI), a community development organization in Boston, that has used the
CLT model as part of its holistic strategy to redevelop a neighborhood that has suffered from redlining, arson, and abandonment. DSNI is perhaps the only community organization in the United States to have attained the power of eminent domain to acquire land for housing development. ${ }^{41}$

Dari sejumlah contoh kebijakan yang dilakukan di negara lain, maka kebijakan subsidi dipandang cocok untuk diterapkan di Indonesia. Hanya saja subsidi yang paling pas berdasarkan hasil penelitian ini adalah subsidi dalam bentuk penyediaan tanah bagi pembangunan perumahan masyarakat berpenghasilan rendah. Subsidi tanah ini bisa berasal dari pemerintah, CSR perusahaan swasta, Pengembang Perumahan, tanah wakaf maupun tanah yang dibeli melalui APBD.

\section{Kesimpulan}

Penyediaan rumah bagi masyarakat berpenghasilan rendah masih terkendala dengan harga perumahan yang mahal. Mahalnya harga perumahan tersebut disebabkan karena mahalnya harga tanah. Rumah dapat menjadi murah apabila kepemilikan rumah terpisah dari tanah (azas pemisahan horizontal). Namun tidak semua masyarakat dapat menerima prinsip kepemilikan rumah tersebut. Paradigma masyarakat tentang perumahan masih menunjukkan bahwa rumah harus menyatu dengan tanah. Begitupun pada masyarakat berpenghasilan rendah. Hanya $2 \%$ dari responden yang dapat menerima paradigma kepemilikan rumah yang terpisah dari tanah.

Penelitian ini mencoba memberikan solusi untuk perubahan paradigma masyarakat tentang kepemilikan rumah yang terpisah dari tanah. Hasil penelitian menunjukkan bahwa masyarakat berpenghasilan rendah dapat menerima prinsip pemisahan rumah dari tanah dengan beberapa prasyarat, yaitu adanya ketahanan lingkungan, ketahanan sosial, ketahanan ekonomi, harga terjangkau,

40 Mueller, et al., "Making the Case for Affordable Housing: Connecting Housing with Health and Education Outcomes", Journal of Planning Literature, Vol. 21, No. 4, August 2013, hlm. 371-385.

41 James Maehan, "Reinventing Real Estate. The Community Land Trust As a Social Invention in Affordable Housing", Journal of Applied Social Science, Vol. 8, No. 2, September 2014, hlm. 113-133. 
prosedur mudah, security tenure dan adanya ruang public untuk tempat bersosialisasi.

Berdasarkan hasil penelitian dirancang model pengembangan paradigma masyarakat kearah azas pemisahan horizontal. Model tersebut menawarkan bahwa pengembangan paradigma dapat dilakukan melalui dua kegiatan yaitu: peningkatan wawasan/ pemahaman masyarakat berpenghasilan rendah dan pemenuhan kebutuhan/harapan masyarakat. Peningkatan wawasan dan pemahaman dapat dilakukan melalui aktivitas pelatihan, sosialisasi dan komunikasi yang dilakukan oleh para pemangku kepentingan, khususnya pemerintah, LSM dan Perguruan tinggi. Sedangkan Pemenuhan prasyarat dapat dilakukan melalui beberapa cara, yaitu subsidi perumahan oleh pemerintah, memanfaatkan CSR perusahaan swasta untuk penyediaan tanah, penggunaan tanah wakaf, dan pemanfaatan bank tanah yang berasal dari sumbangan pengembang perumahan dan atau pembelian tanah melalui APBD.

\section{DAFTAR PUSTAKA}

\section{A. Buku}

Parlindungan, A.P., 1983, Aneka Hukum Agraria, Alumni, Bandung.

\section{B. Artikel Jurnal}

Addison, Carey, et al., "Smart Growth and Housing Affordability. A Review of Regulatory Mechanisms and Planning Practices", Journal of Planning Literature, Vol. 28, No. 3, August 2013.

Leavitt, Jacqueline, et al., "Low Wage Workers and High Housing Costs", Labor Studies Journal, Vol. 30, No. 2, Juni 2005.

Meehan, James, "Reinventing Real Estate. The Community Land Trust As a Social Invention in Affordable Housing", Journal of Applied Social Science, Vol. 8, No. 2, September 2014.

Mueller, et al., "Making the Case for Affordable Housing: Connecting Housing with Health and Education Outcomes", Journal of Planning Literature, Vol. 21, No. 4, August 2013.

Ribot, J.C., et al., "A Theory of Access", Rural Sociology, Vol. 68, No. 2, 2003.

Roestamy, Martin, "Pengadaan Tanah dalam Perspektif Sosiologi Hukum", Jurnal Living Law Vol. 7, No. 1, Januari 2015.

Schlager, E., et al., "Property Rights Regimes and Natural Resources: A Conceptual Analysis,"
Land Economics, Volume 68, No.3, 1992.

Varady, David P. dan Carole C. Walker, "Housing Vouchers and Residential Mobility", Journal of Planning Literature, Vol. 18, No. 1, August 2003.

\section{Makalah}

Roestamy, Martin, "Concept of Land Bank Institutional Development for Land Supply for Low-Income Housing Development (MBR)", Makalah, Brain Inspired Cognitive System Conference, Universitas Djuanda, Bogor, 2017.

Mungkasa, Oswar, "Penyediaan Tanah Bagi Perumahan LIP melalui Bank Tanah (Land Bank) Berbasis Tata Ruang (Kasus: DKI Jakarta)", Makalah, Focus Group Discussion held by The HUD Institute of Indonesia, Grand Zury Hotel, Tangerang, 15 Juni 2017.

\section{Hasil Penelitian/Tugas Akhir}

Roestamy, Martin, 2008, Kepastian Hukum atas Kepemilikan Rumah dan Bangunan Gedung oleh Investor Asing dikaitkan dengan Asas Nasionalitas dalam Sistem Hukum Pertanahan Indonesia, Disertasi, Program Doktor Ilmu Hukum, Universitas Padjadjaran, Bandung. , et al., 2014, Model Pengembangan Sistem Hukum perumahan Bagi Masyarakat 
Berpenghasilan Rendah Yang Layak Secara

Teknis, Ekonomi dan Sosial, Laporan Penelitian, Universitas Djuanda, Bogor.

Rahmawati, Rita, 2013, Konflik-Konflik Kehutanan di Jawa Barat dan Kalimantan Barat, Disertasi, Program Doktor, Institut Pertanian Bogor, Bogor.

\section{E. Artikel dalam Antologi dengan Editor}

McKean, M.A., "Nesting Institutions For Complex Common-Pool Resource Systems", in J. Graham, et al., 2002, Proceedings of the 2nd International Symposium on Landscape Futures, Institute for Rural Futures and University of New England, London,

\section{F. Internet}

Biro Pusat Statistik, "Jumlah Penduduk Miskin September 2014 Mencapai 27,73 Juta Orang. Website BPS", http://www.bps.go.id/index. php/brs/1026, diakses tanggal 25 Oktober 2016.

Kementerian Pekerjaan Umum dan Perumahan Rakyat, "Pemerintah Lakukan Penyederhanaan Perizinan Guna Percepat Program Sejuta Rumah", http://pu.go.id/berita/11482/ Pemerintah-Lakukan-PenyederhanaanPerizinan-Guna-Percepat-Program-SejutaRumah, diakses tanggal 25 Oktober 2016.

Biro Pusat Statistik, "Persentase Rumah Tangga menurut Provinsi dan Status Kepemilikan Rumah Milik Sendiri, 1999-2015". https:// www.bps.go.id/linkTabelStatis/view/id/1541, diakses Tanggal 25 Oktober 2016.

Kementerian Pekerjaan Umum dan Perumahan Rakyat, "Pemerintah Lakukan Penyeder- hanaan Perizinan Guna Percepat Program Sejuta Rumah", http://pu.go.id/berita/11482/ Pemerintah-Lakukan-PenyederhanaanPerizinan-Guna-Percepat-Program-SejutaRumah, diakses tanggal 25 Oktober 2016.

Detiknews, "Ini 10 Raksasa Properti di Indonesia", https://finance.detik.com/properti/d1967977/ini-10-raksasa-properti-indonesia, diakses pada tanggal 25 Oktober 2016.

\section{G. Peraturan Perundang-undangan}

Undang-Undang Nomor 5 Tahun 1960 tentang Pokok-Pokok Agraria (Lembaran Negara Republik Indonesia Tahun 1960 Nomor 104, Tambahan Lembaran Negara Republik Indonesia 2043).

Undang-Undang Nomor 28 Tahun 2002 tentang Bangunan Gedung (Lembaran Negara Republik Indonesia Tahun 2002 Nomor 134, Tambahan Lembaran Negara Republik Indonesia Nomor 4247).

Undang-Undang Nomor 20 Tahun 2011 tentang Rumah Susun (Lembaran Negara Republik Indonesia Tahun 2011 Nomor 108, Tambahan Lembaran Negara Republik Indonesia Nomor 5252).

\section{H. Lain-Lain}

Wawancara Tim Peneliti STRANAS 2016 dengan responden masyarakat Citayam, Cilebut, Bojonggede dan Tanjung Priok pada periode Juni hingga Agustus 2016 